\title{
Monoclonal Antibody L6
}

National Cancer Institute

\section{Source}

National Cancer Institute. Monoclonal Antibody L6. NCI Thesaurus. Code C2372.

A murine IgG2a monoclonal antibody with potential antineoplastic activity. Monoclonal antibody L6 binds to the L6 antigen, a cell surface glycoprotein overexpressed in many carcinomas, and induces antibody-dependent cell-mediated cytotoxicity and complement-dependent cytotoxicity against L6-expressing tumor cells. This agent may be conjug ated with various toxins in order to targ et their cytotoxic activity to tumor cells expressing the $\mathrm{L} 6$ antigen. ( $\mathrm{NCl} 04)$ 